\title{
Blog-Based Project of Student Affairs Management Platform for Counselors in Colleges and Universities
}

\author{
Xiaolu Ye \\ Sichuan University of Arts and Science, Dazhou, China \\ Email:yexiaolu0396@163.com
}

How to cite this paper: Ye, X. L. (2019). Blog-Based Project of Student Affairs Management Platform for Counselors in Colleges and Universities. Advances in Applied Sociology, 9, 86-94.

https://doi.org/10.4236/aasoci.2019.92008

Received: January 14, 2019

Accepted: February 23, 2019

Published: February 26, 2019

Copyright $\odot 2019$ by author(s) and Scientific Research Publishing Inc. This work is licensed under the Creative Commons Attribution International License (CC BY 4.0).

http://creativecommons.org/licenses/by/4.0/

\section{(c) (7) Open Access}

\begin{abstract}
An internet cored society has formed quietly into the development of information technology. Since the gradually increased scale of institutions of higher education, problems of student affairs management like too many students and inefficient number of counselors have stood out. Under such a new circumstance, it is undoubted a pioneering attempt to change the previous mode of management, and build a Blog based Project of Student Affairs Management Platform for Counselors in Colleges and Universities. Through introducing internet technology into student affairs management, combining counselor's management with ideas such as sharing, creativeness, personality and communication is shown by the current populating Blog. On one hand, this platform can effectively manage to add information. On the other hand, it can help realizing the instant communication between counselors and students thus making the work of students' mental health and ideological and political education more diverse. Besides, both the theory and designing principles have been got after the questionnaire survey and feasibility study of this attempt.
\end{abstract}

\section{Keywords}

Blog, College Counselor, Student Affairs Management

\section{Introduction}

With the development of information technology, internet has taken off in China and brought profound changes in people's life, an internet cored society has formed quietly. Under such a new circumstance, it is undoubted a pioneering attempt to change the previous mode of management and build a Blog-based Project of Student Affairs Management Platform for Counselors in Colleges and 
Universities through introducing internet technology into student affairs management. On one hand, this platform will effectively manage to add information.

On the other hand, every student will be able to share anything he/she wants to talk about with their teachers under a more independent and free circumstance, which can even be anonymous, via internet. This indeed will shorten the mental gap between teachers and students eliminate students' pressure from teacher's authority and help making the work of students' mental health and ideological and political education more diverse.

\section{Significance of Introducing Blog in College Counselor Student Affairs Management}

\subsection{Solve Problems with College Counselor Student Affairs Management}

Besides the leader and educator of a grade, counselor is also the instructor and guide to students in political, learning and life aspects. More importantly, it's the attachment to teachers, students and their parents. However, each counselor has more than two hundred students, their work often related to every aspect of students' thoughts, study, and work. There is no enough time and energy for counselors to get familiar with every student's condition (Wang, 2007), so the efficiency of their job lowered and led to a situation that many students never communicate with its counselor direct for a whole semester or even more.

\subsection{Promote and Perfect College Counselor Student Affairs Management with Information Means}

Nowadays, many colleges and universities though have built up their own student information management system due to the democratization of internet technology. They generally provide only part of services as management of students' status (including digital photos), grades, rewards and punishment, dormitory arrangement and management of student leaders, and lack of communication between counselor and students. Therefore, bringing Blog in college counselor student affairs management to form a Blog based equal, open, shared and co-created platform for teachers and students can both effectively manage increasing information and achieve prompt communication between teachers and students.

\subsection{Cultivate the Spirit of Exploration and Creativity of Students}

Blog is a new technology and easy to learn and operate. Using the Blog-based platform can not only help students mastering this technology but also helps stimulating their interests in learning, making them learning voluntary and cultivating their spirit of exploration and creativity (Zhu, 2008).

\section{Information of Blog}

\subsection{Concept of Blog}

As a newly populated word, the translated word weblog is the Network log or 
just Blog for short. Blog is the abbreviation for Weblog, the combination of web and $\log$ (Fang, 2005). Log means diary, which refers to recoding things one done, met or felt each day. Web means web pages, which refers to record and release information about Internet. Blog hadn't got its rigorous definition till now and the most accepted one is: Blog is an incessant updated publishing way to express one's personal ideals whose content is chronically ordered (Chen et al., 2003).

\subsection{Characteristics of Blog}

The obvious feature of Blog lies in its simplicity and diversified forms. Blog has surpassed the manifestation of other social media and made it easy about everyone to learn and use. It has four conspicuous characteristics as follows:

\subsubsection{Easy to Use}

To have a personal website, one must learn a lot of Internet skills. However, without difficult network methods one can also has a Blog, and publishes messages as long as he can type and send email.

\subsubsection{Combination of Individualism and Openness}

Blog is a comprehensive tool for people to show themselves and to communicate with others. Bloggers can publish their experiences and reflections at any time on Blog so their interests and knowledge background are reflected through their publishing contents. In addition, every Blog is open so that each user is able to surf others' Blog and reply their opinions.

\subsubsection{Sharing}

The biggest difference between Blog and ordinary diary lies in the former one has the open Internet information platform as its support, which determines it's sharing. With uniform format providing RSS abstract, Blog becomes conveniently and effectively shared.

\subsubsection{Globalization}

Every person has the right to show their opinions on Blog and with typing we can make them heard by the world through Internet. Meanwhile (Ye \& Zhou, 2010), we can gain others' thoughts and information when surfing their Blog.

\section{Feasibility Studies for the Blog Based Project of Student Affairs Management Platform for Counselors in Colleges and Universities}

Since each counselor in university has several hundred students at the same time, they have few chances to communicate with each other directly. Then it is crucial how to fully use information technology to help counselors knowing every student's actions and thoughts and handling problems among students instantly, how to attract students to Blog and bring it into play to build a great atmosphere for them to share information and thinking, and how to give students independence, cultivate individual education and enhance their vigor of studying. 
I believe that the Blog based management platform can better solve those problems than traditional education website or traditional management software.

First of all, any counselor or student can build up their own Blog space due to its simple registration, short time building and few complicate website development technologies. Applying for a Blog is basically zero cost and zero technical knowledge (Zhang et al., 2007). Each student has his or her own space in that platform and they can design as well as to protect the space according to their own interests. Such a platform dramatically promotes students' active participation and good for building their personification. Besides publishing their own ideas and exchanging thoughts with others, students can also conceal their private information. Being a huge communication platform, this website enables counselors and students to surf public information in shared space and discuss with each other in a group to finish a specific task together thus enhancing cooperation between students.

Secondly, bringing Blog, an internet communication tool of massive functions, can meet the prompt exchanges of counselors and their students. Moreover, they can have more emotional conversations and this is the biggest difference between the Blog based platform and other educational platforms. The communication between Blog is more specialized [7], more emotional and counselors can choose different educational strategies to solve different problems. With this platform, all the students in one class are able to be the host of the Blog thus realizing fully free management, independent exchange and cooperative learning. This is also the incomparable advantages of Blog based platform.

There are some mature education Blogs and counselor management software here in China but none of them have combined Blog and management software together which is able to not only share and handle all kinds of information data but also contact with students. Through the questionnaire given to part from the counselors and students in China West Normal University, seventy point five students think it is necessary to build a Blog-Based Project of Student Affairs Management Platform for Counselors in Colleges and Universities and eleven point four of them believe it is very important to do so, these two groups covered eighty-one point nine percent of the overall students in the survey (Figure 1). While among counselors, seventy five percent of them view it is necessary and sixteen percent argues it is very important which added up to ninety one percent of the total number (Figure 2). So it is not only the need of modern university students but also a way to enhance work efficiency in universities to build the Blog based management platform.

\section{Theory of Blog Based Student Affairs Management Platform}

\subsection{SLI Theory}

SLI (student Learning Imperative) Theory came from a report on American College Personnel Association (ACPA). A new viewpoint was put up by the 


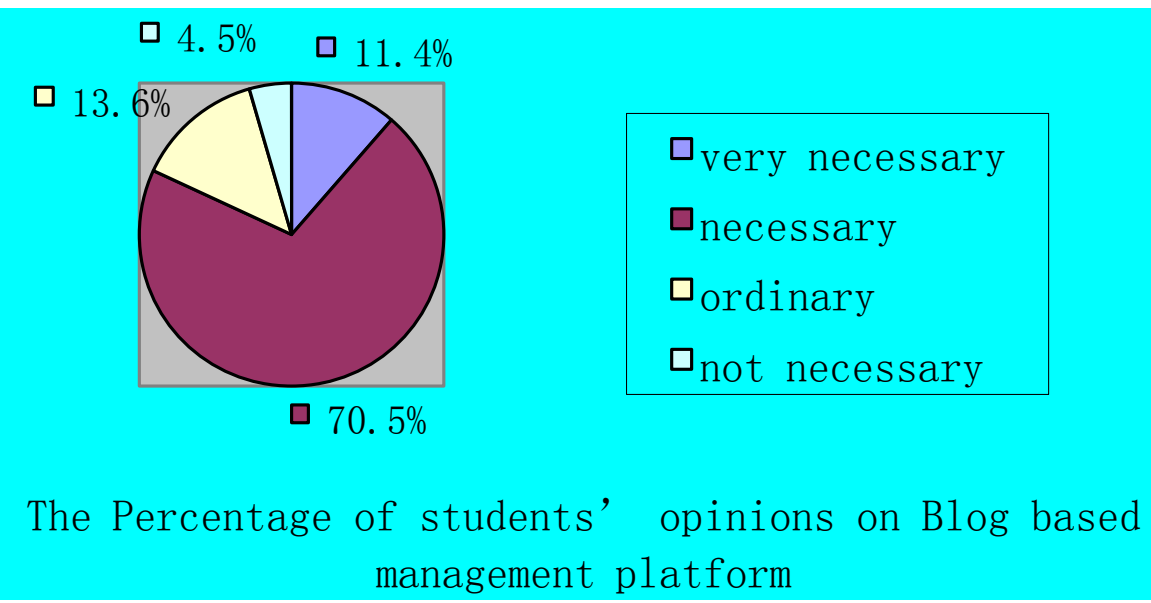

Figure 1. The Percentage of students' opinions on Blog based management platform.

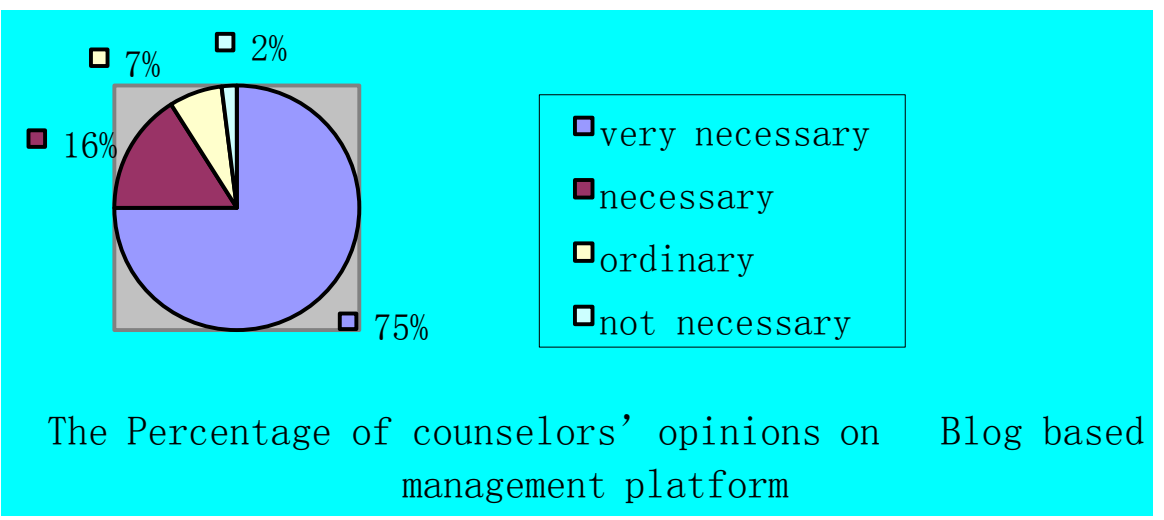

Figure 2. The Percentage of counselors' opinions on Blog based management platform.

ACPA that Student Learning Imperative: Implication for Student Affairs, which short as SLI. This theory has drawn much attention to America higher education circles after its appearance and has become a new basic theory to instruct the management of student affairs. A student affairs department serves students is a feature put forward in SLI that means: The student affairs department is the supplement of academic work, and taking improving students' study and individual development as its ultimate purpose. Student affair staff should take their responsibility to help students' learning and development and use techniques to encourage their students. Student affair staff ought to join hands with other organizations and departments to facilitate students' grades and development. Student affairs include expert on students' problem, learning environment and teaching process. All the policies and plans must be based on information about studies on students' study and other specific evaluation made by academics. A serial subjected by SLI was released by ACPA in its professional magazine "Development of University Students" in March to April, 1996. SLI gives student affair staffs a chance to further thinks about their responsibilities and specify their mission in the future. That's "we student affair personnel should regard promoting students' study as our task and fundamental goal”. 


\subsection{Human-Based Learning Theory}

According to the Human-Based Learning Theory, every person has capacity and dynamism to develop one's potential and can freely choose their life direction and value and at the same time responsible for them. Real study includes learners themselves instead of providing them truth only. At the same time teacher's roles need to be changed into not value recognition process nor have the so called standard answer, but only a person who is willing to help students exploring possible answers and a promoter. Teacher's job is to promote students' development not to train or teach them. Teacher is only the prompter, inspirer and helper of a student.

\subsection{Software Engineering Theory}

Software Engineering belongs to Engineering, which apply theory and knowledge to practice. In order to develop high-quality software, software engineering has learned from traditional engineering principles and methods including computer science, mathematics and management science. Computer science helps to structure models and algorithms. Engineering Science is used to establish criteria, evaluate costs and make choice. Management science is as the management of plan, resource, quality and costs.

\section{Design of Blog Based Student Affairs Management}

\subsection{Principles of the Design of Blog Based Student Affairs Management}

\subsubsection{Recognition of Early Stage}

The preliminary work of developing a system are surveys and analysis of demand and the future development speed and performance condition are all decided to these jobs. Inadequate understanding, analysis of the platform may lead to many problems like imperfect function designing, unreasonable student management module, which will bring lots of troubles to the development later. Due to the important role the early period job plays in the development of platform, in-depth researches and surveys need to be made before developing and only in this way can we save labor, time and have a desired effect.

\subsubsection{Usability}

Platform operating system should be simple. Notifications are detailed, exact and adequate. Design, color and fonts of the layout structure are clear. Navigation on platform is definite. Prompts are accurate. Meanings of front indicative graphics are consistent with the same pictures backward. It should be easy to link and jump to other pages. It has the virtue of good interface of human-computer interaction. The interface is beautiful and has an accord overall style.

\subsubsection{Scalability}

Scalability refers to the ease of expanding new functions of a soft ware. In order 
to solve new problems and meet new demands of students in the future management, modular structures have been adopted during the program designing and several interfaces were kept to expand new functions. The scalability of a systematic structure was made on the basis of changeable demands.

\subsubsection{Practicability}

The purpose of developing Blog-Based Project of Student Affairs Management Platform for Counselors in Colleges and Universities is to put it into use in teachers' management. Using this platform to improve the current condition of management and facilitate communications between head teachers and students. An impractical platform is wasting labor and money even if it was developed. Because of this, head teachers and students in colleges and universities must be involved in the whole process of the development. Technology developers should bear in mind that this technology is ought to serve teachers and students, so as to try their best to meet the demands of teachers' effective management and students' direct interaction, avoid developing for technologies or leading disconnection between technology and reality.

\subsubsection{Standardization}

A system needs to follow the international standard and in accordance to related rules and standards of the development of hardware and software of computers. Making sure the system and its running environment is unified and standardized.

\subsubsection{Safety and Reliability}

Make sure the internet cannot be illegal login and only those in association level can visit internet data and information.

\subsection{Module Designs of Blog Based Student Affairs Management}

User identities such as student, counselor and manager were set up in the management platform and each identity has unique adaptive authorities. The module design of the platform is shown in Figure 3.

The main function modules in this platform are respectively registration and login, school announcement, data download, student management and site search. Here are the brief introduction of the major contents and functions of each module as follows.

\subsubsection{Registration and Login Module}

This module is the procedure that each user has to experience which is verifying the identity of the user before accessing platform. The system would suggest the user registering if he or she has not registered yet. Only registered users can enter into the Blog (individual space).

\subsubsection{School Announcement Module}

This module is accessible to every user as they open the home page. Some announcements of classes and school were put on it to help students' prompt notice. 


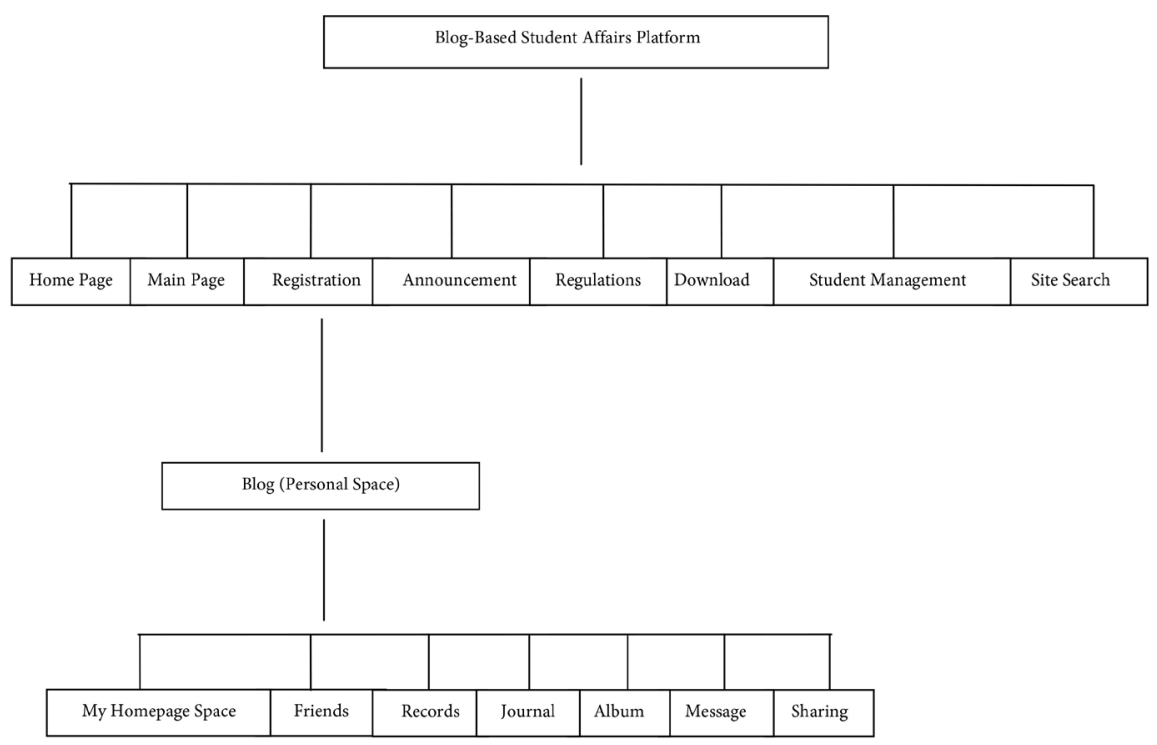

Figure 3. Flowchart of module design of the Blog-based student affairs management.

\subsubsection{Rules and Regulation Module}

This module mainly releases some rules and regulations in class and school and aim to making students know what they should follow.

\subsubsection{Data Download Module}

This module covers all the forms of class and school; each student can download the forms that they need from this module when they opening the main page.

\subsubsection{Student Management Module}

There are three sub modules under the student management module, which are management of student status, student performance management and dormitory management.

\subsubsection{Site searches Module}

More and more resources will be created during the use of this platform. To facilitate resources using, this platform gives Users a specific module to search needed information on it. After submitting the key word of what they want to surf and choosing search pattern, the related information is presented at once.

\section{Conclusion}

Student management plays an important role in the process of training people. Due to the expanding size of colleges and universities in recent years, differences between students' abilities and shortage of counselors are coming out. Combining counselor management with those ideas exemplified by the current populating Blog such as sharing, creativeness, personality and communication can effectively manage the adding information on one side, and on the other side, it can help realizing the instant communication between counselors and students. It is not only the need of modern university students but also a way to enhance work efficiency in universities to build the Blog-based management platform. 


\section{Conflicts of Interest}

The author declares no conflicts of interest regarding the publication of this paper.

\section{References}

Chen, X. D., Wang, X. H., Gao, D. D., \& Zhang, J. P. (2003). Blog Culture and Modern Educational Technology. China Educational Technology, 3, 17-21.

Fang, X. D. (2005). Memorabilia of China Blog (Edition 1.3). http://Blog.sina.com.cn/s/Blog_55c7e4ab0100gess.html

Wang, X. B. (2007). Application of Computer Network in College Student Management. Test Report, 42, 13-14.

Ye, X. L., \& Zhou, X. (2010). Exploration of Blog in Educational Application. Science \& Technology Information, 6, 24-25.

Zhang, H. F., Mei, X. W., \& Zhao, T. F. (2007). Study on Application of Blog in Information Technology Teaching Strategies. China Educational Technology, 12, 93-96.

Zhu, X. H. (2008). The Advantages of Blog in High School's Information Technology Teaching. China Educational Technology, 8, 85-87. 